\title{
The Preparedness for Re-emerged and Emerging Infectious Diseases: A Lesson Through Outbreak of Middle East Respiratory Syndrome Coronavirus (MERS-CoV) in South Korea
}

\author{
Sungmo Je, Wonjun Bae, Jiyeon Kim, Seung Hyeok Seok ${ }^{*}$ and Eung-Soo Hwang ${ }^{*}$ \\ Department of Microbiology and Immunology, and Global Center for Infectious Diseases, Seoul National University \\ College of Medicine; and Institute of Endemic Disease, Seoul National University Medical Research Center, \\ Seoul, Korea
}

The Middle East respiratory syndrome coronavirus (MERS-CoV) causes severe acute respiratory disease and systemic dysfunction that may eventually lead to the death of the patients. After MERS-CoV was first diagnosed in the South Korea, in May 2015, it affected 186 individuals and claimed 37 lives in short span of time (case fatality rate $=19.9 \%$ ). Compared to MERS-CoV in the Middle East, MERS-CoV in South Korea appeared to be more transmissible, and induced multiple human-to-human transmission. These knowledge gaps caused the failure of early prevention, and disseminated MERS-CoV brought out a great loss of lives and economy. The MERS-CoV outbreak revealed the potential weakness of public health system in South Korea, and promoted the reestablishment of preventive strategies for imported infectious diseases. In these regards, we analyzed the potential for additional import of re-emerged and emerging infectious diseases, such as dengue fever, malaria, chikungunya fever and hepatitis A, from Africa or South-East Asia. Then we suggest the investment expansion and the administration of global networks for effective research and control for newly or re-emerged infectious diseases. In conclusion, it is required to expect and prepare for the surveillance of the importation of foreign pathogens, and constitute the internal collaborative systems for rapid detection and risk communication. In addition, we should take an active part in the global networks to perform rapid preparedness and control for re-emerged or emerging infectious diseases.

Key Words: Middle east respiratory syndrome coronavirus, Infectious disease, Control and prevention, Global network

\section{INTRODUCTION}

메르스 코로나바이러스(Middle East Respiratory Syndrome
Coronavirus; MERS-CoV)는 2012년 처음 중동에서 발견된 바이러스로서 사람에게 감염되었을 때에 중증의 호흡기 질환을 유발하여 사망에 이르게 한다 (1). 특히 고령자 또 는 기저 질환을 지닌 환자의 경우 높은 감염율과 치사율

\footnotetext{
Received: October 12, 2015/ Revised: November 11, 2015/ Accepted: November 16, 2015

* Corresponding author: Eung-Soo Hwang, MD, PhD. Department of Microbiology and Immunology, Seoul National University College of Medicine, 103 Daehak-ro, Jongno-gu, Seoul 03080, Korea.

Phone: +82-2-740-8307, Fax: +82-2-743-0881, e-mail: hesss@snu.ac.kr

*Corresponding author: Seung Hyeok Seok, DVM, PhD. Department of Microbiology and Immunology, Seoul National University College of Medicine, 103 Daehak-ro, Jongno-gu, Seoul 03080, Korea.

Phone: +82-2-740-8302, Fax:+82-2-743-0881, e-mail: lamseok@snu.ac.kr

** The research was performed using literatures and services at the Seoul National University College of Medicine. This work was supported partly by a grant (no. 2014K1B1A1073282) from Ministry of Science, ICT and Future Planning, Republic of Korea and partly by the Education and Research Encouragement Fund of Seoul National University Hospital.

(c) This is an Open Access article distributed under the terms of the Creative Commons Attribution Non-Commercial License (http://creativecommons.org/license/by-nc/3.0/).
} 


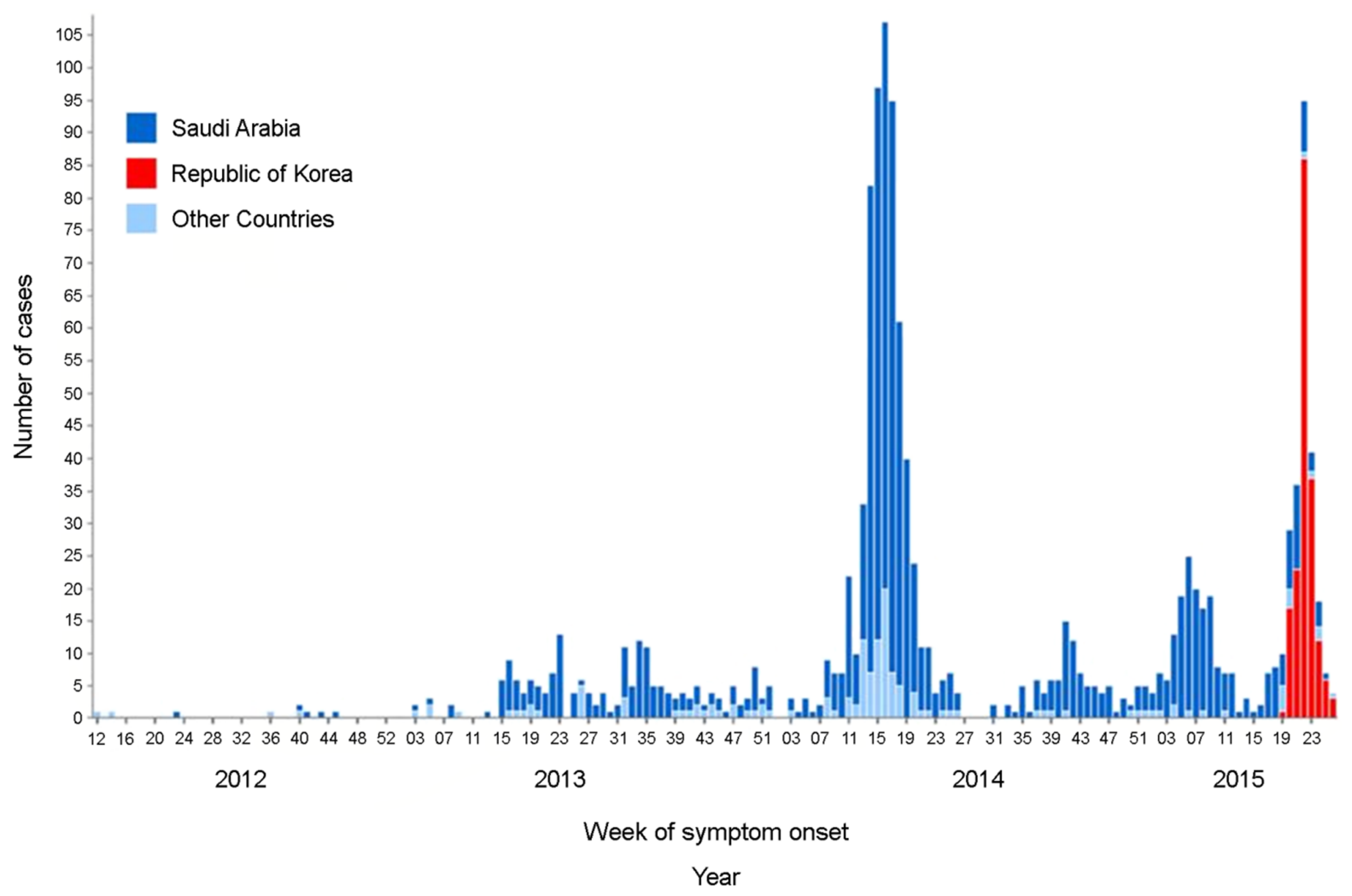

Figure 1. Epicurve of confirmed MERS cases and deaths in Republic of Korea, China, Saudi Arabia and other countries. Data from WHO

을 나타내고 있다. 현재까지 중동, 아시아, 아프리카, 미 국 등 26 개국에서 발생하여 약 1,600 명 이상의 감염자와 600 명 이상의 사망자가 보고되고 있다(case fatality rate $=$ $38.3 \%)(2,3)$. 여러 지역에서 메르스 발생은 직접적이거 나 간접적으로 중동 지역(사우디 아라비아, 카타르, 아랍 에미리트, 쿠웨이트, 오만, 요르단 등)을 매개로 이루진 것 으로 알려져 있다.

메르스 코로나바이러스는 베타-코로나바이러스 C형으 로 분류되고 있다. 이러한 계통의 코로나바이러스는 박쥐 와 밀접한 관련이 있으며, 특히 애기 박쥐와 관련이 깊은 것으로 알려져 있다 $(4,5)$. 2012년 처음 발생한 메르스 환자 또한 단봉 낙타로부터 감염된 것으로 추정되고 있 으며, 이렇게 사람과 낙타에서 분리된 메르스 코로나바이 러스는 박쥐에서도 유사하게 확인되고 있다 (6). 하지만 최근 역학 분석에 의하면 초기에 밝혀진 동물로부터의 감 염 사례 외에 사람 간의 감염 전파 사례가 증가하고 있다 (7). 사람 간 2 차 감염자의 대부분은 가족, 의료종사자 등
1 차 감염자와의 밀접 접촉자로 알려져 있다. 이러한 사람 간의 전파는 전세계 여러 지역으로의 감염 확산에 영향 을 미치고 있는 것으로 분석된다 (8).

2015년 한국에서 발생한 메르스 코로나바이러스는 아 라비아 반도 이외 지역에서 가장 많은 감염자를 유발하 였다(Fig. 1) (9). 5월 20일 국내 첫 발생을 기점으로 하여 186 명의 감염자와 36 명의 사망자가 보고되었으며, 16,000 명 이상의 일반인과 의료종사자가 격리 조치되었다. 현재 에도 5 명의 환자가 기저 질환을 치료 중에 있다. 중동 지 역의 여행 및 교류가 활발히 이루어지고 있어 메르스 코 로나바이러스의 전파 위험에 노출되어 있다 (10). 한국에 서의 대규모 발생은 메르스 코로나바이러스의 감염 전파 에 대한 새로운 특징들을 제시해주었으며, 또한 고위험성 감염 질환에 대처하는 한국 보건의 현황과 한계점을 드러 내 보여주었다.

최근 기후 변화 및 세계화와 더불어 에볼라, 메르스와 같은 신종 또는 재발생 감염병이 늘어나고 있다. 이러한 
감염병들은 주로 아프리카, 동남아 지역에서 발생하지만 여행 및 교역의 증가로 인하여 일부 지역의 문제가 아닌 전세계적인 관심으로 이어지고 있다. 한국의 경우에도 해 외 여행과 교역이 해마다 증가하는 추세에 있으며, 특히 동남아 지역에서 감염원과의 접촉이 늘어나고 있다. 따라 서 동남아 등지에서 유행하고 있는 풍토병 및 신종 감염 병에 대한 경각과 주의가 필요하며, 동시에 신종 감염병 의 유입에 대한 체계적인 대응책의 확립이 요구된다.

이 연구에서는 메르스 코로나바이러스의 국내 유입 전 파에 대한 대응과 이후 복구 과정에서 드러난 국내 보건 환경의 주요한 문제점들을 고찰하여 개선방향을 제시하 고, 또 앞으로 유입될 수 있는 신변종 감염병에 대한 분 석과 이에 효과적으로 대응하기 위한 향후 방안을 조사 해보았다.

\section{METHODS}

본 연구를 위하여 PubMed, Google과 Google Scholar를 통해 검색한 2012년 1월부터 2015년 10월까지 게재, 발표 된 논문 및 보도 자료를 이용하여 데이터 분석을 수행하 였다. 검색을 위하여 'Middle East Respiratory Syndrome', 'MERS-CoV', 'MERS-CoV in camel', 'MERS-CoV transmission', 'MERS-CoV animal', 'MERS-CoV vaccine', 'MERS-CoV treatment', 'MERS-CoV diagnosis' 등의 단어를 이용하였다. 신 종 감염병 검색을 위하여 동일한 검색 사이트를 통하여 'dengue', 'chikungunya fever', 'avian influenza', 'hemorrhagic fever, ebola', 'ebolavirus'의 단어를 이용하였다. 또한 World Health Organization (WHO)의 'Middle East respiratory syndrome coronavirus' 자료, 미국 Centers for Disease Control and Prevention (CDC)의 'National Notifiable Diseases Surveillance System' 자료, National Institutes of Health의 'Study of Ebola survivors opens in Liberia' 자료, 한국의 질병관리본부의 '메르스 현황', '감염병 감시 연보', 법무부 출입국의 '2014 출입국·외국인 정책 통계 연보' 및 한국관광공사의 '국민 해외관광객 주요 행선지 통계'을 분석하여 결과 예측에 이용하였다. 질병 연구관심도 조사를 위하여 Pubmed에서 'Ebola', 'MERS', 'Chikungunya', 'Avian Influenza' 단어를 이용 하여 검색하였고 추출된 논문의 변화 추세를 분석하였다.

\section{RESULTS}

전 세계적 메르스 코로나바이러스의 분포 및 발생 특성

메르스 코로나바이러스의 동물 감염 분포

2012년 메르스 코로나바이러스가 사람의 중증 호흡기 질환의 원인으로서 처음으로 확인된 이후, 2013년 8월, 단봉 낙타(Camelus dromedarius)가 사람의 감염에 관계되 어 있다는 것이 밝혀졌다. 이후 메르스 코로나바이러스의 감염이 사람과 접촉이 잦은 낙타를 통하여 주로 이루어 진다는 사실을 근간으로, 최근 연구에서는 중동 지역과 아프리카 지역의 단봉 낙타에서 메르스 코로나바이러스에 대한 항체 유무를 조사하였다. 그 결과 중동 지역(사우디 아라비아, 요르단, 오만, 카타르)의 단봉 낙타에서는 90 $100 \%$ 수준의 항체 양성율을 나타내었으며 (11 14), 아프 리카 지역에서는 약 30 100\%까지 양성율을 나타내었다 $(15,16)$. 이러한 결과는 중동 지역의 단봉 낙타에서 메르 스 코로나바이러스가 만연하고 있음을 나타내고 있다. 또 한 낙타와 자주 접촉할 수 있는 아프리카 지역에서도 메 르스 코로나바이러스의 전파가 이루어지고 있으며, 실제 보다 낮은 수준의 감염 진단이 이루어지고 있음을 추정 할 수 있다.

\section{메르스 코로나바이러스의 사람 감염 분포}

메르스 코로나바이러스의 사람에서의 발병은 주로 중 동 지역을 중심으로 나타나고 있다. 특히 중동 지역 중에 서도 약 $90 \%$ 가 사우디 아라비아에서 보고되어 가장 높 은 발생 빈도를 나타내었다. 2015년 국내 발생의 경우, 186 명의 감염자가 보고되었으며, 이는 전세계적으로 사우 디 아라비아 외에 가장 높은 발생 정도를 보여주었다. 중 동 지역과 한국 외 유럽, 아시아 국가나 미국에서도 발생 보고는 있으나 2012년 이후 10건 미만의 발생으로 매우 낮은 발생 빈도를 나타내었다 (3).

메르스 코로나바이러스의 사람 간 감염은 매우 제한적 으로 알려져 있다. 기존 연구에 의하면 1 차 메르스 감염 환자와 접촉한 집안 식구들의 2 차 감염율은 $5 \%$ 수준으로 드러나 사람 간 감염 전파율은 낮은 것으로 분석되었다 (17). 또한 의료진의 감염 정도를 조사하였을 때 1 27\% 수준으로 사스 코로나바이러스(11 57\%)보다 낮은 수준에 속하지만, 의료종사자들이 일반인들보다 매우 높은 감염 위험성을 지니고 있음을 나타내고 있다 (18). 2012년 1년 간 사우디 아라비아 전 지역에서 수집한 10,009 개의 샘플 
Table 1. Vaccines for MERS-CoV under development

\begin{tabular}{lllc}
\hline \hline Vaccine type & Viral antigen & Experimental models & Reference \\
\hline Adenoviral vector & Full-length S & BALB/c Mice & {$[21]$} \\
MVA vector & Full-length S & BALB/c Mice & {$[22]$} \\
\hline \multirow{2}{*}{ Recombinant protein } & S-RBD (358-588) & Rabbits & {$[23]$} \\
\hline Consensus DNA & S-RBD (377-662) & BALB/c Mice & {$[24]$} \\
Nanoparticles & Full-length S & Mice, camels, NHPs & {$[25]$} \\
\hline
\end{tabular}

MVA, Modified vaccinia virus Ankara; RBD, Receptor-binding domain; NHPs, Non-human primates

에서 항체를 측정한 결과 일반인보다 낙타와 자주 접촉 하는 직종, 목동(15배), 도축장 종사자(23배) 등에서 더 높 은 양성율을 나타내었고, 여자보다 남자에서 더 높은 양 성율을 나타내었다 (19). 또한 항체 양성 반응을 나타낸 사람들의 평균 연령은 실제 감염된 환자의 평균 연령보다 더 낮은 것으로 나타났으며, 이러한 결과를 통하여 이전 에 낙타와 접촉하지 않은 고연령자들이 감염될 경우 병 증 발현이 쉽게 일어나날 수 있음을 추정해 볼 수 있다.

\section{백신 개발 연구 동향}

메르스 코로나바이러스의 Spike (S) 1 subunit과 세포 수 용체 DDP4 (Dipeptidyl peptidase 4)의 접촉에 의한 바이러 스의 세포 내 유입 과정이 밝혀진 이후로 이를 타겟으로 한 다양한 백신 개발이 곳곳에서 이루어지고 있다(Table 1) (20 26). 바이러스 벡터, 재조합 항원, DNA, 나노입자 등을 이용한 많은 백신 후보군들이 개발 중이지만 많은 전문가들은 시장 동향과 규모에서나 그 개발 과정 자체에 서 많은 어려움이 있을 것으로 예상하고 있다 $(20,27)$. 아 직까지도 메르스 코로나바이러스가 병원성을 나타내는 기 전이 정확히 알려져 있지 않아 S1 subunit 외 백신 개발을 위한 효율적인 타겟 또한 제시하지 못한 실정이다. 효과 적인 백신의 타깃을 발견하였다 하더라도 동물 실험, 임 상 실험을 통하여 안전성 및 효율을 검증하기까지 6년 정도의 시간을 예상하고 있으며, 약 5억 달러(약 5 천 6 백 억원)의 비용이 소모될 것으로 예상되고 있어 개발에 많 은 어려움이 있다.

한국의 감염 특성 분석

국내에서 발생한 메르스 감염은 기존 중동 등지에서 발생한 메르스와 다른 특징을 보여왔다. 기존의 중동 지 역에서 발생한 메르스 감염의 경우 (1) 높은 사망률(35
Table 2. The characteristics of MERS-CoV in South Korea

\begin{tabular}{lll}
\hline \hline & $\begin{array}{c}\text { MERS-CoV } \\
\text { in Middle East }\end{array}$ & $\begin{array}{c}\text { MERS-CoV } \\
\text { in South Korea }\end{array}$ \\
\hline $\begin{array}{l}\text { Mortality } \\
\text { Transmission }\end{array}$ & About 40\% & $\begin{array}{l}\text { About 20\% } \\
\text { High, Superspeading }\end{array}$ \\
$\begin{array}{l}\text { Third-order } \\
\text { infection }\end{array}$ & A few & Many, Severe \\
$\begin{array}{l}\text { Major infection } \\
\text { source }\end{array}$ & Camel-to-human & $\begin{array}{l}\text { Human-to-human } \\
\text { in hospital }\end{array}$ \\
\hline
\end{tabular}

$40 \%$, (2) 낮은 전파력, 주로 근접 접촉 감염, (3) 전파에 따른 병원성 감소, (4) 낙타 등 동물에 의한 감염의 특성 을 보였다. 하지만 국내 메르스 감염의 경우 (1) 사망률 약 $20 \%$, (2) 높은 전파력 보유, 슈퍼 전파자 등장, (3) 3 차 감염 및 사망 발생, (4) 주로 병원 내 감염 등의 특성을 나타내어 기존 보고된 중동 지역의 메르스 감염과 다른 특성을 나타내었다(Table 2) $(10,28,29)$.

하지만 한국에서 분리된 메르스 코로나바이러스의 염 기서열을 분석했을 때, 기존 중동에서 분리된 바이러스와 큰 차이가 없는 것으로 밝혀졌다 (7). 이러한 결과는 메르 스 코로나바이러스의 병원성에 대한 새로운 분석과 관점 을 제시하였으며, 전세계적으로 관련된 연구를 확산시키 는 역할을 하고 있다(Fig. 2).

국내 발생 메르스 대응 과정의 문제점

역학 조사 전문 인력 부족

메르스 초기 대응에 실패했던 주요한 이유 중 하나는 


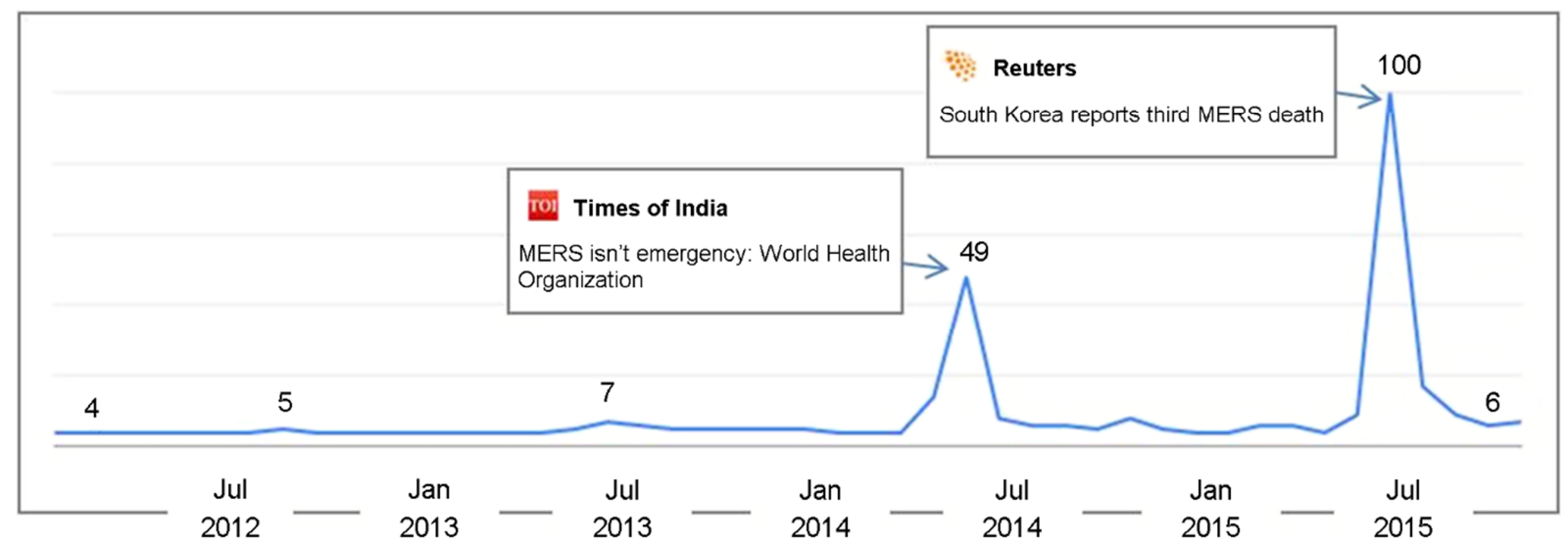

Figure 2. Search interest for "MERS" over time in Google search. Numbers represent search interest relative to the highest point on the chart. Boxes represent news headlines closely related to search terms at the time.

정확한 역학 조사 분석과 적용의 부재였다. 초기 메르스 확진 환자는 여러 병원을 다녀온 후 확진되었지만, 그 중 일부의 병원만이 감염관리 대상에 포함되었으며, 그 외의 병원은 관리에서 제외되었던 것이다. 이러한 병원들은 그 동안 특별한 규제나 대책이 없이 진료행위가 계속되었으 며, 메르스의 발생이 더욱 확산된 이후 관리 규제 대상에 추가되었다.

초기 부실한 역학 조사의 원인은 전문적인 역학 조사 인력 부족에 의한 것으로 분석되고 있다. 메르스 발생 초 기 역학 조사관은 34 명이었지만, 이 중 2 명만이 정규직 공무원이었고, 32 명은 전문적인 교육을 받지 못한 군복무 대체 공중보건의로 알려졌다 (30). 이러한 전문 인력의 부 재는 광범위하고 면밀한 역학 조사와 위기 분석의 어려 움으로 이어져 효과적인 전파 차단 대응책을 제시할 수 없는 원인이 되었다.

\section{위기 의사 소통 부족}

국내 메르스 발생 시 메르스의 확산 과정 중 감염 병 원 정보에 대한 미공개 대책이 초기 대응의 실패 원인의 하나로서 분석되었다. 세계보건기구의 관련 의사 소통 가 이드라인 원칙에는 신뢰관계 구축, 신속한 발표, 투명한 정보공개 등이 제시되어 있지만, 위기 정보의 공개와 국 민과의 소통 부족으로 중앙 대처에 대한 불신이 더욱 심 화되었다. 2015년 5월 20일 처음 메르스가 발생하였지만, 메르스 발생과 전파가 급속하게 늘어남에 따라 6월 7일 '메르스 확진 및 경유 의료기관 명단'을 공개하여 관련된
병원의 관리를 강화하였다 (31). 하지만 그 동안 병원 정 보 미공개 대책에 의하여 감염이 발생하였던 병원에 아 무런 정보 없이 방문하여 추가적으로 다수의 환자 또는 보호자가 감염에 노출될 수 있는 상황이 일어나거나 많 은 수의 시민들이 격리되는 등 감염 전파 차단에 큰 난항 을 격었다.

또한 위기 소통 부재의 반작용으로 나타난 불확실한 정 보의 비공식적 전파는 사회 혼란을 가중시켰다. 메르스 발생 시 정확한 발생 병원의 정보를 접할 수 없는 상황에 서 관련 기관은 자체적으로 메르스 관련 병원 명단을 공 개하였고, 이러한 정보는 정확한 사실의 확인 없이 SNS 나 인터넷을 통하여 비공식적으로 배포되어 국민의 혼란 을 가중시켰으며, '메르스 괴담이라는 말이 생겨날 정도로 사회의 불안을 조성케 하였다.

\section{감염관리 병원 시설 및 전문 의료 인력 부족}

에볼라 사태 이후 고위험성 감염병 환자의 관리를 위 하여 국가에서는 19 곳의 지역 거점 병원을 지정하여 운 영 중이다 (32). 지정된 병원들은 감염병원체의 외부 전 파를 막을 수 있는 음압 격리 시설을 보유 및 운영하고 있는 것으로 알려져 있다. 하지만 국내 메르스 발생 이후 감염 환자 관리를 위한 음압 격리 병동은 여러 병원에서 시설의 불완전성이 드러났고, 이로 인하여 병원 내 감염 을 유발하는 원인으로 작용하였다. 상당수의 음압 격리 병동은 필수 구성 시설인 전실이 없거나 병실 내 공조 시 스템이 부적절하게 순환 가동되는 것으로 밝혀져 감염원 
의 효율적인 차단에 적합하지 않은 것으로 드러났다.

또한 이번 메르스 사태에서는 감염관리 병원 시설 뿐 만 아니라 의료 인력의 부족이 드러났다. 고위험성 감염 병 대처를 위한 전문 의료 인력 확보를 위하여 관련된 훈 련이 시행되었지만, 훈련의 범위는 감염내과, 예방의학에 관련된 소수의 의료진만을 대상으로 이루어졌다. 하지만 이번 메르스 사태와 같이 발생 상황이 장기화, 광역화되 면서 전문적인 교육을 받은 의료 인력 보충의 어려움이 드러나 신속한 대응에 차질을 가져왔다. 또한 장기 진료 를 시행해 온 의료진들의 피로, 탈진 정도가 심각한 수준 으로 나타나 환자의 지속적인 관리의 어려움과 의료진들 의 추가적인 감염 가능성이 문제로 제기되었다.

뿐만 아니라 이번 메르스 사태에서 응급실의 과밀화는 병원 내 감염 확산의 주요한 원인으로 지적되었다. 국내 의료 환경의 오랜 문제점으로 지적되어온 응급 진료 현 장은 실제 환자 수에 비해 입원 병실이나 진료 가능한 의료 인력이 매우 부족한 것으로 알려져 있다. 실제 이번 메르스 환자 186 명 중 $48 \%$ 정도가 응급실에서 발생하여, 국내 응급 진료 체계의 구조적인 문제점들은 신종 감염병 에 효과적인 대처를 위하여 신속히 개선되어져야 할 부 분이다 (10).

고위험성 감염 대처를 위한 보건 교육과 시민 의식 부재

메르스 발생 시 감염인과의 밀접 접촉자는 질병관리본 부로 보고된 후 관할 보건소의 관리 하에 자가 격리 조 치가 실시된다 (33). 자가 격리 대상자에 대해 보건소에 서는 일일 능동모니터링을 실시하고 질병관리본부로 보 고하여 관리하는 체계를 갖추고 있다. 국내 메르스 첫 발 생 이후 최고 6,729 명을 대상으로 자가 격리가 시행되었 지만, 지역 보건소에서는 해당자 전원을 면밀히 모니터링 하기에 어려운 것으로 드러났다 (34). 또한 자가 격리제가 대상자의 자율적 협조에 의존하여 이루어졌기 때문에 격 리 대상자의 올바른 수칙의 이해와 준수가 뒤따르지 않 을 경우 제대로 된 격리 차단이 어렵게 된다. 실제 언론 을 통해 격리 대상자가 무단 이탈하여 외부에서 활동을 한 것으로 수 차례 보도되어 국민들의 불안을 증폭시켰다. 이러한 현상은 격리자들의 시민 의식과 감염 보건 교육 의 부족과 함께, 엄격한 법적 제재의 부재와 관리 인력 부 족 등 전반적인 감염 발생 관리 체계의 미비로 인한 것으 로 분석된다.

메르스 전파 확산의 문화적인 요인으로서 지나치게 여
러 병원을 방문하여 여러 의사에게 진료받기 원하는 환 자들의 습관(Doctor shopping)을 들 수 있다. 이러한 Doctor shopping 현상과 함께 친인척에 의한 잦은 병문안 문화 는 국내 메르스의 병원 내 감염을 늘렸던 특이적 요인으 로 분석되고 있어, 불필요한 습관과 의식을 개선해나가기 위한 보건 교육과 홍보가 이루어져야 할 것으로 사료된다.

\section{복구 과정의 문제점}

병원 폐업과 업무정지로 인한 병원 및 의료진의 물질 적 피해 복구

메르스 사태 이후 추가적인 피해를 줄여나가기 위해서 는 1 차적 발생 피해로부터의 신속한 회복을 이루어내는 것이 필요하다. 병원 내 감염이 주를 이루었던 이번 메르 스 발생 특성을 고려할 때, 사회 구조적 회복을 위하여 우선적으로 병원 내 물질적인 피해의 복구 문제의 고찰 이 필요하다.

메르스 발생으로 인해 감염과 관련된 특정 병원은 일 정 기간 영업정지와 폐업으로 물질적 손실이 발생했다. 대한병원협회 보도에 따르면 메르스 환자가 발생했거나 치료한 88 개 병원에 생긴 손실액이 5,000 억원이 넘는 것 으로 조사되었다. 구체적으로 메르스 환자를 직접 치료하 거나 진료한 병원 49 곳과 메르스 환자가 발생하거나 경 유한 병원 41 곳 등 88 개 병원에서 5,496 억원의 직접적인 손실이 발생했다 (35). 하지만 정부와 병원 간에 피해액과 피해범위에 대한 시각의 차이 및 손실 보전을 위한 예산 부족으로 인하여 메르스 발생 후 피해 복구에 어려움을 격고 있는 상황이다.

\section{퇴원환자 및 격리해지자 모니터링 시스템 실시}

메르스 발생 이후 효과적인 복구를 위하여 메르스 감 염 후 완치 환자와 격리해지자에 대한 장기적인 모니터 링과 관리 정책이 필요하다. 2012년 첫 발생 이후 현재까 지 감염 후 치료 환자에 대한 장기적인 모니터링과 분석 은 충분히 이루어지지 못한 상황이다. 국내에서도 메르스 발생이 더 이상 없고 일부 기저 질환 환자가 남아있으나 나머지 완치 환자는 퇴원하였고, 격리자들은 모두 해제되 었다. 메르스 완치 및 격리 해제 이후 환자의 후유증 발 생 모니터링과 혈청 내 항체 생성 및 무증상 바이러스 감지에 대한 연속적인 조사가 필요하다.

2007년 아프리카에서 에볼라 발생 이후 생존자들의 신 체 변화를 2년 이상 추적 조사했을 때, 시력 이상, 청력 이상, 관절염 등의 후유증이 발견되었다 (36). 국내 메르 
Table 3. Imported cases of re-emerged and emerging infectious diseases in South Korea, 2014*

\begin{tabular}{lrrrrrrrrrrrrrr}
\hline \hline & 2001 & 2002 & 2003 & 2004 & 2005 & 2006 & 2007 & 2008 & 2009 & 2010 & 2011 & 2012 & 2013 & 2014 \\
\hline Dengue fever & 6 & 9 & 14 & 16 & 34 & 35 & 97 & 51 & 59 & 125 & 72 & 149 & 251 & 164 \\
Malaria & 67 & 36 & 64 & 38 & 45 & 30 & 35 & 29 & 26 & 51 & 64 & 53 & 60 & 80 \\
Shigellosis & 10 & 10 & 6 & 23 & 44 & 20 & 41 & 62 & 35 & 104 & 107 & 42 & 65 & 38 \\
Typhoid fever & 13 & 11 & 10 & 12 & 19 & 25 & 19 & 10 & 12 & 20 & 31 & 22 & 14 & 22 \\
Hepatitis A & 0 & 0 & 0 & 0 & 0 & 0 & 0 & 0 & 0 & 0 & 22 & 18 & 18 & 21 \\
Measles & 0 & 1 & 2 & 0 & 1 & 5 & 2 & 1 & 1 & 1 & 3 & 2 & 3 & 21 \\
Influenza A & 0 & 0 & 0 & 0 & 0 & 0 & 0 & 0 & 1494 & 17 & 0 & 0 & 0 & 0 \\
Chikungunya & 0 & 0 & 0 & 0 & 0 & 0 & 0 & 0 & 0 & 0 & 0 & 0 & 2 & 1 \\
fever & & & & & & & & & & & & 0 & & \\
\hline
\end{tabular}

*Data from 2014 Infectious disease annual report published by the Korea Centers for Disease Control and Prevention [39].

스 환자 또한 대부분이 40 대 이상의 고령자로 분석되고 있어, 추후 지속적인 모니터링을 통해 메르스 바이러스의 감염 이후 신체적, 정신적 영향에 대해 장기적으로 분석 하고 관리할 필요가 있다. 메르스 환자 대부분이 일정 기 간 외부와 격리되었거나 사회적 편견을 받음으로써 발생 할 수 있는 정신적인 피해 가능성을 고려해야 한다. 이렇 게 수집되어 분석된 정보는 메르스 코로나바이러스에 의 한 차후 합병증 및 잠재적 영향력에 대한 추가적인 정보 를 제공해줄 수 있을 것이다. 현재로서는 향후 관리 및 신체적 재활을 위한 지원, 사회적·경제적 활동으로의 복 구를 위한 구체적 계획이 제시되어 있지 않은 실정이다.

\section{국내 유입 가능한 신종 감염병의 대비 방안}

\section{해외 여행 추세에 따른 유입 가능한 신종 감염병}

최근 한국인의 해외 방문 추세를 분석하였을 때, 2000 년 550만명에서 2014년 1천 6백만명으로 꾸준히 증가해 오고 있다 (37). 2014년 한국관광공사 통계를 기준으로 최 근 한국인의 해외 여행 추세를 조사하였을 때, 중국, 일 본, 미국, 홍콩, 필리핀, 태국, 베트남, 싱가포르, 대만, 말 레이시아 순으로 높은 여행 빈도를 나타내었다 (38). 이 들 상위 10 개국 중에서 중국, 일본, 미국을 제외한 나머 지 7 개국이 동남아 지역에 위치한 점들을 고려할 때, 동 남아에서 유행하는 신종 감염병들이 국내에 유입될 수 있 는 가능성을 염두해 두어야 한다. 실제 2014년 신고된 주 요 해외 유입 감염병을 살펴 보면, "뎅기열(41\%), 말라리 아 $(20 \%)$, 세균성이질(10\%), 장티푸스 $(6 \%), \mathrm{A}$ 형 간염(5\%),
홍역 $(5 \%) "$ 순으로 조사되었고, 이 질병들의 주요 유입 국 가로는 "필리핀, 인도네시아, 베트남, 인도, 중국, 캄보디 아, 태국, 말레이시아 등"의 아시아 지역(약 $81 \%$ )과 "가 나, 적도기니 등"의 아프리카 지역(약 $16 \%$ )으로 조사되 었다(Table 3) (39). 최근 해외에서 유입된 주요 바이러스성 질병의 추세를 분석했을 때, 뎅기열의 경우, 필리핀, 인도 네시아, 태국, 말레이시아 등에서 가장 많이 유입된 것으 로 나타났다(Table 4). A형 간염의 경우, 필리핀, 인도, 중 국, 미얀마 등지에서 유입된 것으로 분석되었으며, 홍역 은 필리핀, 중국, 베트남, 싱가포르에서 유입되었다. 주요 질병들 모두 필리핀에서 가장 많은 수가 유입되었고, 미 국, 일본을 제외한 동남아권 상위 여행국에서 과반 이상 유입된 것을 알 수 있다. 그 외 여행의 빈도는 낮지만, 캄 보디아, 인도 등에서 유입되는 경향이 있다 (39). 이렇게 최근 동남아 지역의 여행 증가와 함께 동일 지역의 국가 들로부터 유입된 감염병 발생이 증가하는 추세를 보여주 고 있으며, 이에 대해 적절한 대비책 마련이 시급한 것으 로 사료된다.

국내에 유입 가능한 주요한 신종 감염병인 뎅기열, A형 간염, 홍역, 치쿤구니야열, 조류 인플루엔자의 특성을 살 펴보았을 때, 아래와 같은 특성을 지닌다 (40).

뎅기열(Dengue fever)

뎅기열은 모기를 통해 전염되는 뎅기 바이러스(dengue virus)에 의한 질환으로 갑작스런 고열 증세를 나타나게 된다. 주로 열대, 아열대 지역에서 발생하고 있으나 기후 변화로 인하여 점차 넓은 지역으로 퍼져나가는 추세이며, 
Table 4. Imported cases of Dengue fever, Hepatitis A, and Measles in South Korea, 2014*

Dengue fever

\begin{tabular}{lcccccccc}
\hline \hline & Philippines & Indonesia & Thailand & Malaysia & Cambodia & Vietnam & India & Others \\
\hline No. of confirmed cases & 56 & 29 & 15 & 13 & 10 & 9 & 8 & 24 \\
\hline
\end{tabular}

Hepatitis A

\begin{tabular}{lcccccccc}
\hline \hline & Philippines & India & China & Myanmar & Singapore & Cambodia & Unknown & Others \\
\hline No. of confirmed cases & 4 & 4 & 3 & 2 & 1 & 1 & 3 & 3 \\
\hline
\end{tabular}

Measles

\begin{tabular}{lcccc}
\hline \hline & Philippines & China & Vietnam & Singapore \\
\hline No. of confirmed cases & 11 & 5 & 4 & 1 \\
\hline
\end{tabular}

Bold characters represent the 10 most visited countries in 2014.

*Data from 2014 Infectious disease annual report published by the Korea Centers for Disease Control and Prevention [39].

국내 유입 발생 또한 증가하고 있다. 특정 뎅기 바이러스 형에 감염되었다가 치유된 후 출국하여 다른 뎅기 바이 러스형에 감염된다면 뎅기열 또는 뎅기출혈열 등의 중증 증상을 보일 수 있으므로 한번 감염되었던 사람의 경우 뎅기 바이러스 유행 지역에 여행할 때는 모기에 물리지 않도록 각별히 조심할 수 있도록 안내해주는 시스템 확 립이 필요하다. 뎅기열 치료제는 아직 개발되지 않았으며 대증요법을 통하여 치료 중이다. 백신 또한 현재 개발 중 으로 아직은 임상시험단계에 있어 치료 적용은 수년 후 에나 가능할 것으로 보인다.

\section{A형 간염(Hepatitis A)}

$\mathrm{A}$ 형 간염 바이러스(Hepatitis A virus)에 의해 발병하고 있으며, 발열, 구토 등의 증상을 나타낸다. 감염자의 배설 물 속에 많은 양의 바이러스가 발견되기 때문에, 감염된 사람과 접촉이나 바이러스에 오염된 음식이나 식수를 섭 취함으로써 전염될 수 있다. 동남아 지역에서 주로 발생 하고 있으며, 국내에서는 발생 지역을 방문한 여행객들에 게서 감염이 관찰되고 있다.

홍역(Measles)

호흡기로 감염되는 홍역 바이러스(Measles virus)에 의한 질환으로 $90 \%$ 에 이르는 높은 이환율을 가진 급성 유행성 감염병이다. 피부 발진과 고열 등을 동반한다. 과거 유년 기에 아주 흔했었으나 현재는 예방 접종으로 인하여 발
생 빈도가 낮은 편이다. 국내 발생은 적은 편이나 동남아, 아프리카 등 해외로부터 유입되는 사례가 있어 지속적인 관리가 필요하다.

\section{치쿤구니야 열(Chikungunya fever)}

모기를 통해 전염되는 치쿤구니야 바이러스(chikungunya virus)에 의해 발병을 일으키며, 고열과 구토, 근육통 등을 동반한다. 주로 아프리카, 아시아, 태평양에 위치한 섬들 에서 주로 발생되고 있으며, 현재로서는 치료제가 없어서 대증요법으로 치료가 시행된다. 백신 또한 개발되어 있지 않은 현황이라 국내 유입 차단을 위한 주의가 요구된다.

\section{조류 인플루엔자(Avian influenza)}

주로 가금류에 의해 사람에게 전염되고 있으며, 드물게 사람 간 감염이 보고되고 있다. 매년 지역별로 유행하는 타입이 다른 경우가 많아 백신 개발에 어려움을 격고 있 는 실정이다. 오셀타미비르 또는 자나미비르와 같은 항바 이러스 치료제를 이용하여 증상을 경감시키거나 예방 조 치로 타미플루를 이용한다. 하지만 유전적 변이가 빈번하 여 예측이 어렵고, 대유행 가능성을 지니고 있어 감염 발 생에 많은 주의가 요구된다. 현재로서는 감염된 가금류의 박멸을 통해 추가적 감염을 예방하고 있다.

위에서 언급한 신종 감염병들에 대한 관심은 최근에 들어 더욱 증가해 나가는 추세이다. 뎅기열, 치쿤구니야 열, 조류 인플루엔자의 학술 검색 빈도를 조사했을 때, 


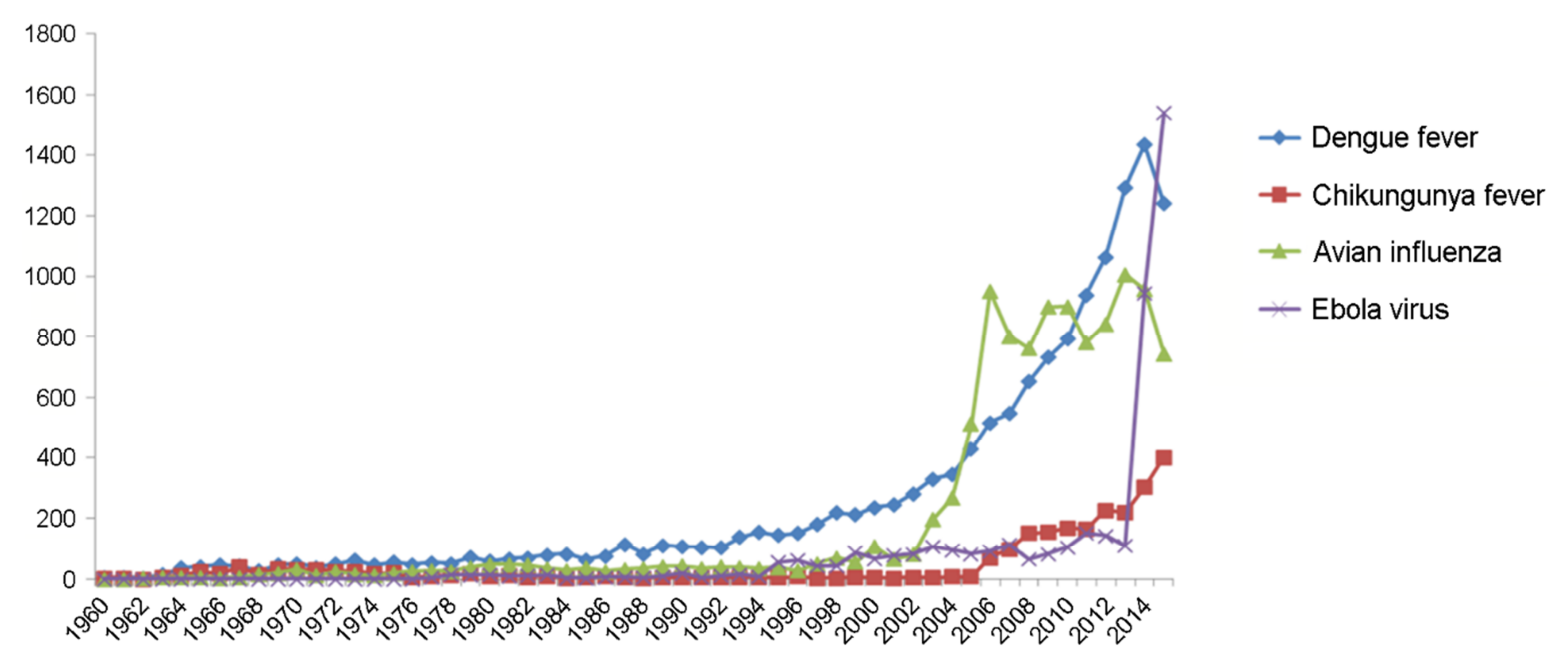

Figure 3. Search term frequency of re-emerged and emerging infectious diseases in Pubmed, 1960-2014.

2000년도 이후 급속하게 증가하는 추세를 보여주고 있다 (Fig. 3) (41). 이러한 현상은 최근 일어나고 있는 기후 변 화와 세계화 및 교역의 증가와 밀접한 관련이 있어 보인 다. 실제 뎅기열의 학술 검색 정도는 국내에 유입되어 발 생 보고된 정도와 비슷한 추세를 나타냄을 알 수 있다 (Table 3). 조류 인플루엔자의 경우, 2002년 홍콩을 비롯 한 아시아 지역의 조류 인플루엔자 발생과 함께 학술 검 색 빈도가 증가하여 지금까지 많은 연구 주제로 다루어 지고 있으며, 아직까지 국지적으로 사람에게 감염되고 있 지만 전세계적으로 높은 위험성을 지니고 있음을 시사하 고 있다.

신종 감염병 대비 연구 투자 확대

세계 주요국의 보건의료산업 $\mathrm{R} \& \mathrm{D}$ 투자는 전체 $\mathrm{R} \& \mathrm{D}$ 의 $20 \%$ 수준으로 유지되고 있지만, 국내 R\&D 투자규모 대비 보건의료 R\&D의 비중은 $7 \%$ 대로 낮은 수준에 해당 한다. 뿐만 아니라 감염병 관련 R\&D 예산은 약 308 억원 (전체대비 $4 \%$ ) 정도로, 5 조원에 달하는 미국 국립 알레르 기·감염병연구소(NIAID) 예산의 $1 \%$ 에도 미치지 못한다 (42). 국가 보건 향상 및 신종 감염병 대응을 위하여 보건 의료 및 감염 관련 $\mathrm{R} \& \mathrm{D}$ 분야의 점진적인 투자 확대가 요구된다.

미국이나 일본 등 선진국에서는 2014년 서아프리카 에 볼라 사태 이후 자국에 감염 전파되지 않았지만 자체적 으로 백신 및 치료제 개발을 위해 연구 추진 중이다 (43
45). 사스, 신종 인플루엔자, 에볼라, 메르스 등 최근 발생 한 고위험성 바이러스성 질환으로 전 세계적으로 여러 차례 어려움을 격었지만, 국내에서는 신종, 고위험성 감 염 질환과 관련된 연구를 전문적으로 수행해온 기관을 찾 기 어렵다. 현재 국내에서 유통되는 신종 인플루엔자, 결 핵 등 주요 감염병 분야의 백신들은 대부분 수입에 의존 하여 수급하고 있는 실정이다. 뿐만 아니라, 앞에서 언급 한 것처럼 동남아 지역을 통해 국내 유입 가능성이 높은 뎅기열병, 치쿤구니야열병 등에 대한 조기 진단 및 치료 기술의 부재는 최근 메르스 사태와 같이 질병 발생 시 초 기 대응과 환자 치료에 어려움을 가져올 수 있다. 따라서 국내에 유입될 수 있는 신종 감염병에 효과적으로 대응하 기 위해 현재 유행하거나 새롭게 유입될 수 있는 감염병 의 신속한 진단법과 치료법을 지속적으로 연구할 수 있 는 시설 확충과 투자의 증대가 필요하다.

신종 감염병 대비를 위한 정부 주도의 감염 네트워크 형성

신종 바이러스성 질병을 신속하게 대처하기 위해서는 신종 질병에 대한 신속한 정보의 확보가 우선시 되어야 한다. 각국에서의 해외 질병 정보의 입수는 주로 문헌이 나 현지 방문을 통해 확보되고 있다. 하지만 최근 발생한 에볼라, 사스, 신종 인플루엔자와 같은 질병의 광범위 전 파 가능성을 고려할 때, 각 국에서는 국제적인 협력 네트 워크 체제를 형성하여 감염병에 대한 정보를 공유하고 이 
에 대응하고 있다.

WHO 주최의 International Health Regulation (IHR) 또는 최근 에볼라 사태 이후 미국을 중심으로 발의한 Global Health Security Agenda (GHSA)가 그 대표적 예이다 (46). GHSA에서는 최근 광범위하게 발생하는 감염성 질환 및 생물 테러를 국제적인 보건안보의 위협으로서 인지하고,
이러한 새로운 위험 요소에 대비하여 미국을 중심으로 전 세계 40여 개 국가가 함께 위험 요소에 대한 예방-감지 -대응을 위한 12 개의 행동요령을 설정하고 이행 방안을 구상하고 있다. 또한 2000년 이후 국제수역사무국(Office International des Epizooties; OIE)에서는 국제적으로 넘나드 는 조류 인플루엔자의 관리 및 퇴치를 위해서 국제 협력

\section{NEDSS}

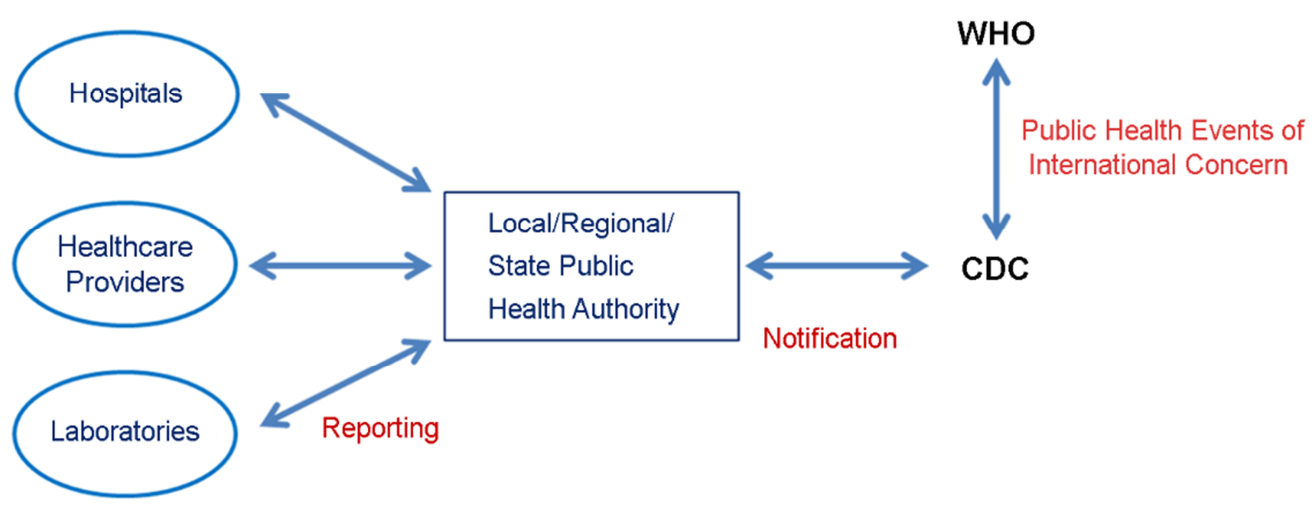

Figure 4. National Electronic Disease Surveillance System (NEDSS) of CDC

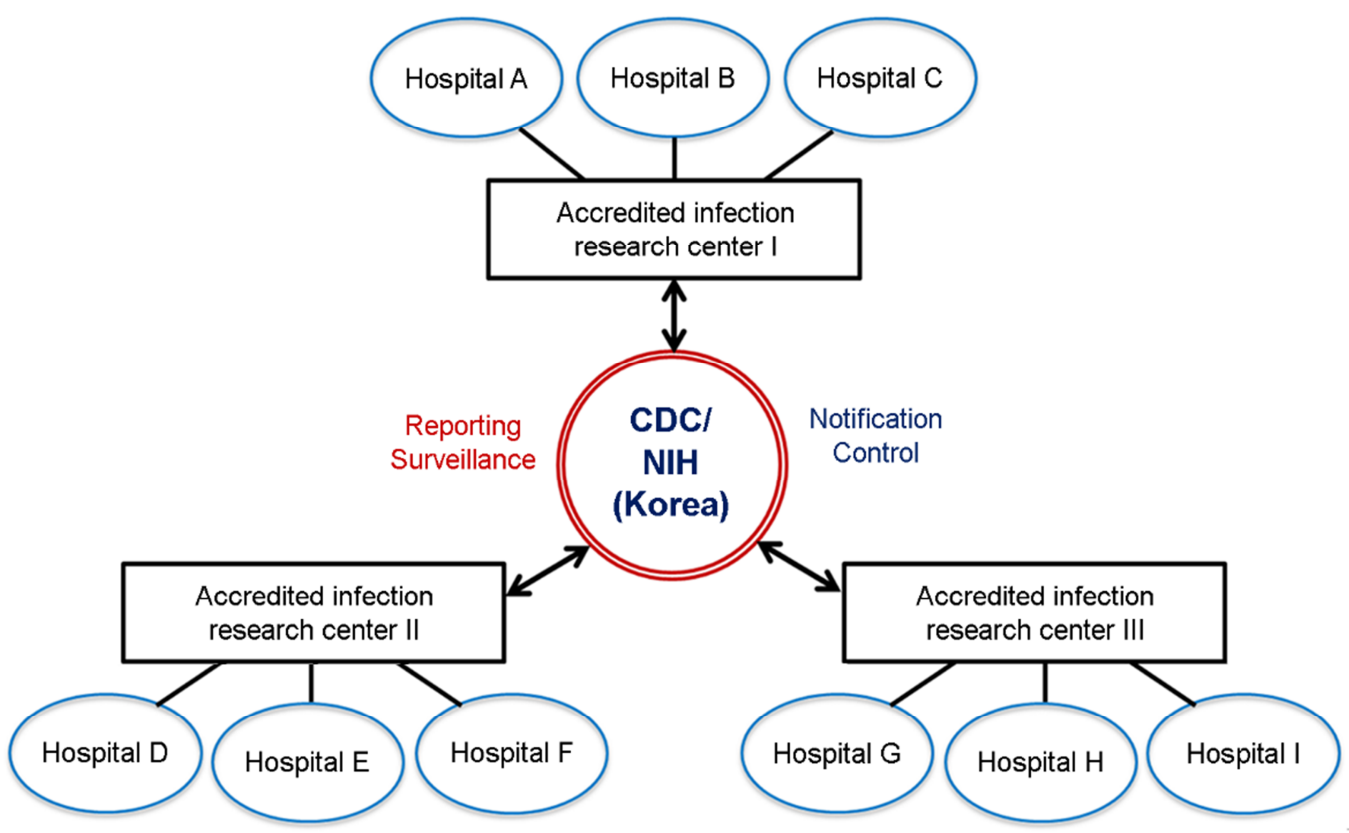

Figure 5. The schematic proposed presentation of the internal collaborative network system for surveillance and control for infectious disease. 
을 강화하고 있다.

이러한 국제 협력 체제의 형성은 감염 질환 발생에 관 한 신속한 정보 입수와 해외 전문가와의 교류를 통한 자 국의 보건 상황의 문제점을 확인하고 보완할 수 있게 해 준다. 해외 여행과 교역이 늘어나고 있는 현 추세에서 국 제 네트워크를 통하여 확보할 수 있는 구체적인 해외 감 염 발생 정보는 보다 신속하게 자국의 대응 체제를 형성 하는데 도움을 줄 수 있다. 또한 상대적으로 열악한 국내 감염 대응 기술을 보완하기 위하여 해외 현장에서 사용 가능한 최신 기술 및 프로토콜의 입수는 보다 효율적으 로 신종 감염병 유입에 대응할 수 있게 해준다.

국제 협력 네트워크 뿐만 아니라, 정부 주도의 국내 감 염 네트워크의 형성 또한 감염병 대응에 효과적인 방법 이 될 수 있다. 미국의 경우, 생물 테러 및 감염 질환의 확산을 모니터링하기 위하여 국가 전자 질병 관리 시스템 (National Electronic Disease Surveillance System, NEDSS)을 도입하여 시행하고 있다(Fig. 4) (47). 이 시스템을 통하여 모든 병원 및 보건 기관에서의 질병 정보는 전산 처리되 어 $\mathrm{CDC}$ 로 전송되어 중앙 부서에서 관리되고 있다. 상대 적으로 열악한 국내 감염 전문 인력과 인프라를 효과적 으로 이용하기 위하여 국내에서도 거점 기관을 중심으로 감염 네트워크 체제를 구축함으로써, 각 지역의 감염 질 환의 발생을 보다 체계적이며 신속하게 모니터링할 수 있 다(Fig. 5). 지역의 소규모 병원에서 신종 감염이 발생하거 나 지역 감염이 확산될 경우, 감염 전문 인력을 집중시켜 신속한 환자관리와 처치를 진행하고, 질병관리본부와 감 염 전문 인력 간 원활한 소통을 이룰 수 있다.

\section{DISCUSSION}

2015년 국내에 발생한 메르스 코로나바이러스는 유입 된 신종 감염병에 대응하는 한국 보건 상황의 현재 단면 을 보여주었다. 많은 감염 전문가들은 메르스 확산의 주 요한 원인으로서 방역 당국의 안일한 대응, 해외 감염병 에 대한 의료진의 무지와 무관심, 초기 역학 조사의 허술 함을 제시하였다. 실제 미국의 경우, 2014년 4월 메르스 감염 환자가 발생했지만, 효율적인 초기 대응으로 추가적 인 확산이 없이 감염 발생을 차단할 수 있었다. 미국 의 료 당국은 메르스가 자국에 유입될 수 있다는 예측과 함 께 응급 상황을 준비하고 있었으며, 환자의 여행 이력을 통하여 메르스를 확진한 후 신속한 격리 조치를 취하여
감염 확산을 차단하였다. 이러한 사례를 통하여 유입 가 능성이 있는 신종 감염에 대한 예측과 대비 절차의 확립 및 그에 따른 신속한 역학 정보의 분석이 신종 감염병의 차단에 필수적임을 알 수 있다.

뿐만 아니라 메르스 사태를 통하여 드러난 체계적인 역학 조사 전문 인력 부족과 감염관리 병원 시설 및 전 문 의료 인력 부족은 감염관리를 위한 전문 인력 양성과 시설 투자의 중요성을 제시해준다. 메르스 사태 이후 국 가에서 감염 관련 시설 확충과 R\&D 투자를 늘리고 있지 만, 이러한 노력이 단기적으로 끝날 것이 아니라 지속적 으로 이루어질 때, 앞으로 유입될 수 있는 신종 감염병에 효과적으로 대응해나갈 수 있다.

메르스 코로나바이러스의 국내 유입과 전파 경로를 고 려해볼 때, 해외여행을 통한 신종 감염병 유입 가능성과 위험성에 대하여 일반인들을 대상으로 충분한 정보 전달 의 중요성을 알 수 있다. 평상시 일반인들에게 감염 대비 위생교육이 거의 이루어지지 않을 뿐만 아니라, 위기 발 생 상황에서도 피상적인 위생지침의 홍보만 접할 수 있 어서, 이번 메르스 사태에서는 개개인이 불필요할 수준까 지 민감하게 대처하는 부작용을 초래하기도 하였다. 뿐만 아니라 질병관리본부나 지역 보건소에서 홍보하는 감염 정보나 위생지침이 감염 전파 수준에 맞추어 신속하게 제 시되어 소통되지 못하였고, 그 결과 시민들의 역학 조사 비협조, 악성 루머 유포, 허위 신고, 격리 위반 등으로 방 역당국의 역량을 더욱 분산시키고 사회 불안을 조성하였 다. 따라서 감염 대처를 위한 필수 정보와 시민의식 함양 을 위해 신종 감염병에 대한 대처 방안 등의 보건 교육 을 강화하고, 재난 관리 컨트롤 타워를 확립하여 위기 사 태에 있어 정부와 국민 간의 신뢰성 있는 의사 소통을 이 루어 나가야 한다.

앞에서 서술한 바와 같이 국내에서 발생한 메르스 경 우 기존과 다른 감염 특성을 나타내었다. 많은 전문가들 은 이러한 점들에 비추어 아직까지 메르스에 대한 분석 이 부족한 상태라고 표현하였다 (28). 비슷한 예로, 기존 연구 조사에 의하면 아프리카 지역의 낙타에서 메르스 코로나바이러스의 항체가 흔히 발견되는 것으로 알려져 있지만, 아직까지 동일 지역에서 사람의 감염 발생은 보 고되지 않은 상태이다 (16). 이러한 현상은 통계 관리 시 스템이 열악한 아프리카 지역의 부정확한 집계 결과일 수 도 있지만, 메르스 코로나바이러스의 발생 상황들을 고려 해볼 때, 바이러스의 병원성은 사우디 아라비아나 한국과 
같이 현대화된 생활 환경과 밀접한 관련이 있을 수 있다 (23). 실제 중동에서도 타 지역보다 사우디 아라비아에서 매우 높은 발생 빈도를 지니고 있다. 이렇게 환경 변화와 관련된 메르스 코로나바이러스의 병원성 연구는 차후 추 가적인 발생에 대비한 주요한 정보를 제공해줄 수 있다. 따라서 국내에서 발생한 메르스 코로나바이러스도 국내 환경 또는 인종에 따른 병원성 변화에 대한 추가적인 연 구와 고찰이 필요하다.

본 연구에서는 메르스 외에 앞으로 국내 유입 가능한 신종 감염병에 대한 예측과 대비의 필요성을 제시하였다. 분석을 통하여 해외 여행 증가 추세와 함께 여행 빈도가 높은 동남아 지역으로부터 뎅기열, 말라리아, A형 간염과 홍역 등의 질병 유입의 증가를 확인하고 향후 국내에 미 칠 위험성을 예측할 수 있었다. 추가적으로 감염 전파 위 험성을 지닌 치쿤구니야열, 조류 인플루엔자 또한 전 세 계적으로 높은 관심과 주의를 나타내고 있다.

이러한 신종 감염병에 대한 효과적인 대응을 위하여 감 염 연구와 시설을 위한 투자 증대와 함께, 국제적인 네트 워크 형성을 통한 정보의 신속한 교류가 무엇보다 필요 하다. 이번 메르스 사태에서 드러난 것처럼 신종 감염병 에 대한 사전 예측과 예비는 신속한 감염 차단에 필수적 이다. 국제 감염 네트워크를 통한 해외 발생 정보의 교류, 현장 상황 분석, 전문가 교류 등은 신종 감염병의 예측과 예비책 마련에 많은 이점을 가져다 준다. 뿐만 아니라 국 제 네트워크를 국내 환경에서 연구하기 어려운 감염 질 환에 대한 협력 연구를 이룰 수 있게 해준다. 실제 뎅기 열, 치쿤구니야열 등의 바이러스성 질병이 국내에서 증가 하고 있지만 임상샘플 부족으로 연구의 어려움을 겪고 있다. 질병이 빈발하고 있는 동남아 지역의 연구기관과의 협력과 연구자 교류는 임상 연구가 필요한 신속 진단 기 법 및 치료제 개발에 진전을 가져올 수 있다. 아울러 현 지에 감염 관련 연구를 수행할 수 있는 체제를 구축하여 환자샘플 확보 및 연구를 수행하는 것도 한 가지 방안일 수 있다.

전반적인 보건 안보를 다루는 미국 주도의 GHSA 외 에도 감염병 대응을 위한 국제 연구 협력 네트워크로는

Global Research Collaboration for Infectious Disease Preparedness (GloPID-R; http://www.glopid-r.org/)이 있다. 한국 을 포함한 17 개국 참여하고 있는 연구 협력 네트워크로 서 세계적으로 유행 가능성이 있는 신종 혹은 재창궐하는 감염 질환의 발생 시 48시간 이내에 효과적으로 대응할
수 있는 기반 조성을 위한 연구 협력 네트워크이다. 또 한 감염 질환의 백신과 치료제 개발 및 샘플 공유를 위한 국제 협력 네트워크로서 미국과 일본, 유럽국이 참여한 Global Health Security Initiative (GHSI; http://www.ghsi.ca)가 있다. 이러한 국제 네트워크는 감염에 대응한 최신 정보 교류 및 연구 협력을 목적으로 하고 있으며, 미국, 유럽 등의 선진국 위주로 참여가 이루어지고 있다. 최근 한국 도 GloPID-R에 참여하기 시작하였으며, 신종 감염병의 증가에 따라 다국적 네트워크를 통한 감염 대응 및 연구 개발의 국제적 협력은 앞으로 더욱 활성화될 전망이다.

메르스와 같이 신종 감염병의 신속한 이해를 위해서는 다양한 전공을 지닌 국내 감염병 전문가와 보건기관 간 의 활발한 정보공유가 필요하다. 이러한 점에서 국내 감 염 전문 기관의 네트워크 형성은 각 지역 거점의 전문 인력을 이용하여 보다 효율적으로 신종 감염병 발생을 모 니터링 할 수 있게 해준다. 또한 신종 감염병 치료와 관 리에 있어 경험을 지닌 전문가의 의견 수렴 및 유동적인 인력 지원을 통하여 타 현장에서의 효과적인 대응을 가 능케 한다. 뿐만 아니라 메르스 사태에서와 같이 대규모 감염 발생 상황에서도 정부의 관리 대책 본부와 감염 전 문가 네트워크 사이의 효과적인 협력과 소통을 통하여 전 지역의 체계적인 관리 체제를 구성하는 데에 도움을 줄 수 있다.

서아프리카 에볼라 사태 이후 고위험성 감염병 발생은 지역적 수준의 문제가 아니라 전세계적 보건 안보의 위 협으로 인식되고 있다. 실제 한 명의 환자에 의해서 국내 유입된 메르스는 국가적으로 엄청난 물질적 손실과 인명 피해를 가져 왔으며, 사회 전반적인 위축과 불안의 원인 이 되었다. 따라서 고위험성 신종 감염병에 대한 올바른 정보 습득과 대응 방안의 마련은 자국의 보건 안전을 유 지하는 것뿐만 아니라 사회적 안정과 발전, 타국가 간의 원만한 관계 형성을 위해 필수적이다. 새로운 보건 위협 의 문제를 효과적으로 해결해나가기 위해서 국내 전문가 들의 네트워킹을 통하여 국내 환경에 적합한 대응방안을 효율적으로 구상해내고, 감염 발생 상황 시 정부 중심의 신속한 관리 체제를 형성하는 것이 필요하다. 또한 점차 강화되고 있는 국제 협력 네트워크에 능동적으로 참여하 여 해결 방안을 모색하고, 이러한 경험과 지식을 통해 한 국뿐만 아니라 아시아권 내 보건 문제 해결에 있어 선도 적인 역할을 수행해 나가야 한다. 


\section{REFERENCES}

1) Zaki AM, Van Boheemen $S$, Bestebroer TM, Osterhaus $A D$, Fouchier RA. Isolation of a novel coronavirus from a man with pneumonia in Saudi Arabia. N Engl J Med 2012;367: 1814-20.

2) Al-Abdallat MM, Payne DC, Alqasrawi S, Rha B, Tohme RA, Abedi GR, et al. Hospital-associated outbreak of Middle East respiratory syndrome coronavirus: a serologic, epidemiologic, and clinical description. Clin Infect Dis 2014;59:1225-33.

3) World Health Organization. Summary of Current Situation. Literature Update and Risk Assessment. July 2015; http:// www.who.int/csr/disease/coronavirus_infections/risk-assessm ent-7july2015/en/ (Accessed 1 Oct, 2015).

4) Ithete NL, Stoffberg S, Corman VM, Cottontail VM, Richards LR, Schoeman MC, et al. Close relative of human Middle East respiratory syndrome coronavirus in bat, South Africa. Emerg Infect Dis 2013;19:1697-9.

5) Lau SK, Li KS, Tsang AK, Lam CS, Ahmed S, Chen H, et al. Genetic characterization of Betacoronavirus lineage $\mathrm{C}$ viruses in bats reveals marked sequence divergence in the spike protein of pipistrellus bat coronavirus HKU5 in Japanese pipistrelle: implications for the origin of the novel Middle East respiratory syndrome coronavirus. J Virol 2013;87:8638-50.

6) Kayali G, Peiris M. A more detailed picture of the epidemiology of Middle East respiratory syndrome coronavirus. Lancet Infect Dis 2015;15:495-7.

7) Al-Tawfiq JA, Memish ZA. Middle East respiratory syndrome coronavirus: transmission and phylogenetic evolution. Trends Microbiol 2014;22:573-9.

8) Xie Q, Cao Y, Su J, Wu X, Wan C, Ke C, et al. Genomic sequencing and analysis of the first imported Middle East Respiratory Syndrome Coronavirus (MERS CoV) in China. Sci China Life Sci 2015;58:818-20.

9) World Health Organization. Middle East respiratory syndrome coronavirus (MERS-CoV): Epicurve of confirmed cases and deaths in Republic of Korea, China, Saudi Arabia and other countries. July 2015; http://www.who.int/emergencies/merscov/en/ (Accessed 1 Oct, 2015).

10) Korea Centers for Disease Control and Prevention. Middle East Respiratory Syndrome Information. June 2015; http:// www.mers.go.kr/mers/html/jsp/main.jsp (Accessed 1 Oct, 2015)
11) Reusken CB, Ababneh M, Raj VS, Meyer B, Eljarah A, Abutarbush $\mathrm{S}$, et al. Middle East respiratory syndrome coronavirus (MERS-CoV) serology in major livestock species in an affected region in Jordan, June to September 2013. Euro Surveill 2013;18:20662.

12) Reusken CB, Haagmans BL, Müller MA, Gutierrez C, Godeke GJ, Meyer B, et al. Middle East respiratory syndrome coronavirus neutralising serum antibodies in dromedary camels: a comparative serological study. Lancet Infect Dis 2013;13:859 -66 .

13) Hemida MG, Perera RA, Wang P, Alhammadi MA, Siu LY, Li M, et al. Middle East Respiratory Syndrome (MERS) coronavirus seroprevalence in domestic livestock in Saudi Arabia, 2010 to 2013. Euro Surveill 2013;18:20659.

14) Haagmans BL, Al Dhahiry SH, Reusken CB, Raj VS, Galiano $\mathrm{M}$, Myers R, et al. Middle East respiratory syndrome coronavirus in dromedary camels: an outbreak investigation. Lancet Infect Dis 2014;14:140-5.

15) Chu DK, Poon LL, Gomaa MM, Shehata MM, Perera RA, Abu Zeid D, et al. MERS coronaviruses in dromedary camels, Egypt. Emerg Infect Dis 2014;20:1049-53.

16) Reusken CB, Messadi L, Feyisa A, Ularamu H, Godeke GJ, Danmarwa A, et al. Geographic distribution of MERS coronavirus among dromedary camels, Africa. Emerg Infect Dis 2014; 20:1370-4.

17) Drosten C, Meyer B, Müüller MA, Corman VM, Al-Masri M, Hossain R, et al. Transmission of MERS-coronavirus in household contacts. N Engl J Med 2014;371:828-35.

18) Suwantarat N, Apisarnthanarak A. Risks to healthcare workers with emerging diseases: lessons from MERS-CoV, Ebola, SARS, and avian flu. Curr Opin Infect Dis 2015;28:349-61.

19) Müller MA, Meyer B, Corman VM, Al-Masri M, Turkestani A, Ritz D, et al. Presence of Middle East respiratory syndrome coronavirus antibodies in Saudi Arabia: a nationwide, crosssectional, serological study. Lancet Infect Dis 2015;15:559-64.

20) Du L, Jiang S. Middle East respiratory syndrome: current status and future prospects for vaccine development. Expert Opin Biol Ther 2015;15:1647-51.

21) Guo X, Deng Y, Chen H, Lan J, Wang W, Zou X, et al. Systemic and mucosal immunity in mice elicited by a single immunization with human adenovirus type 5 or 41 vector-based vaccines carrying the spike protein of Middle East respiratory syndrome coronavirus. Immunology 2015;145:476-84.

22) Volz A, Kupke A, Song F, Jany S, Fux R, Shams-Eldin H, et 
al. Protective efficacy of recombinant Modified Vaccinia virus Ankara (MVA) delivering Middle East Respiratory Syndrome coronavirus spike glycoprotein. J Virol 2015;89:8651-6.

23) Mou H, Raj VS, van Kuppeveld FJ, Rottier PJ, Haagmans BL, Bosch BJ. The receptor binding domain of the new Middle East respiratory syndrome coronavirus maps to a 231-residue region in the spike protein that efficiently elicits neutralizing antibodies. J Virol 2013;87:9379-83.

24) Du L, Zhao G, Kou Z, Ma C, Sun S, Poon VK, et al. Identification of a receptor-binding domain in the $\mathrm{S}$ protein of the novel human coronavirus Middle East respiratory syndrome coronavirus as an essential target for vaccine development. J Virol 2013;87:9939-42.

25) Muthumani K, Falzarano D, Reuschel EL, Tingey C, Flingai S, Villarreal DO, et al. A synthetic consensus anti-spike protein DNA vaccine induces protective immunity against Middle East respiratory syndrome coronavirus in nonhuman primates. Sci Transl Med 2015;7:301ra132.

26) Coleman CM, Liu YV, Mu H, Taylor JK, Massare M, Flyer $\mathrm{DC}$, et al. Purified coronavirus spike protein nanoparticles induce coronavirus neutralizing antibodies in mice. Vaccine 2014:32:3169-74.

27) National geographic. Why a MERS Vaccine Won't Be Easy. May 2014; http://news.nationalgeographic.com/news/2014/05/ 140523-mers-vaccine-camels-virus-flu-saudi-pandemic-science/ (Accessed Oct 1, 2015).

28) Butler D. South Korean MERS outbreak spotlights lack of research. Nature 2015;522:139-40.

29) Banik GR, Khandaker G, Rashid H. Middle East Respiratory Syndrome Coronavirus "MERS-CoV": Current Knowledge Gaps. Paediatr respir rev 2015;16:197-202.

30) Ministry of Government Legislation. Disease Prevention and Control Law of 2015. Law No. 13392. Act of 6 July 2015.

31) Korea Centers for Disease Control and Prevention. Full disclosure of MERS-hit hospitals. June 2015; http://www.cdc.go.kr /CDC/intro/CdcKrIntro0201.jsp?menuIds=HOME001-MNU 1154-MNU0005-MNU0011\&cid=63293 (Accessed 1 Oct, 2015).

32) Korea Centers for Disease Control and Prevention. National Reorganization of Disease Control System. Sep. 2015; http:// www.cdc.go.kr/CDC/intro/CdcKrIntro0201.jsp?menuIds= HOME001-MNU1154-MNU0005-MNU0011\&cid=65273 (Accessed 1 Oct, 2015).

33) Korea Centers for Disease Control and Prevention. Response
Guidelines for MERS. May 2015; http://www.cdc.go.kr/CDC info/CdcKrHealth0289.jsp?menuIds=HOME001-MNU1132MNU1013-MNU1913\&cid=63072 (Accessed 1 Oct, 2015).

34) Korea Centers for Disease Control and Prevention. Middle East Respiratory Syndrome Information. June 2015; http:// www.mers.go.kr/mers/html/jsp/Menu_B/content_B1.jsp?cid= 26740 (Accessed 1 Oct, 2015).

35) Korean Hospital Association. Compensation for Loss of Hospital in MERS Outbreak. Sep. 2015; https://www.kha.or.kr/ impart/notice/view (Accessed 1 Oct, 2015).

36) National Institutes of Health, Study of Ebola survivors opens in Liberia. June 2015; http://www.nih.gov/news/health/jun2015 /niaid-17.htm (Accessed 1 Oct, 2015).

37) Korea Tourism Organization. Statistics of Korean Tourism. July 2015; http://kto.visitkorea.or.kr/kor/notice/data/statis/profit/ board/view.kto?id=379196\&instanceId=294 (Accessed 1 Oct, 2015).

38) Korea Tourism Organization. Statistics of Korean Departures. Aug. 2015; http://kto.visitkorea.or.kr/kor/notice/data/statis/profit /board/view.kto?id=425044\&isNotice=false\&instanceId=294\& rnum=6 (Accessed 1 Oct, 2015).

39) Korea Centers for Disease Control and Prevention. Infectious disease annual report of 2014. July 2014; http://www.cdc.go.kr/ CDC/info/CdcKrInfo0302.jsp?menuIds=HOME001-MNU 1132-MNU1138-MNU0038\&fid=32\&q type $=\& q \_$value $=$ \&cid=63970\&pageNum= (Accessed 1 Oct, 2015).

40) Korea Centers for Disease Control and Prevention. Travelers Health Information. Oct. 2015; http://travelinfo.cdc.go.kr/ travelinfo/jsp_travelinfo/infect_info/contents_gita/disease2_01_1 .jsp (Accessed 1 Oct, 2015).

41) Pubmed. Results by year. http://www.ncbi.nlm.nih.gov/pubmed/ (Accessed 15 Oct, 2015).

42) Ministry of Strategy and Finance. 2016 Budget. Sep. 2015; http://budget.go.kr/info/2016/budget2016_overview.html (Accessed 1 Oct, 2015).

43) Zhou Y, Sullivan NJ. Immunology and evolvement of the adenovirus prime, MVA boost Ebola virus vaccine. Curr Opin Immunol 2015;35:131-6.

44) Nakayama Y, Aruga A. Comparison of Current Regulatory Status for Gene-Based Vaccines in the US, Europe and Japan. Vaccines 2015;3:186-202.

45) Fusco ML, Hashiguchi T, Cassan R, Biggins JE, Murin CD, Warfield KL, et al. Protective mAbs and Cross-Reactive mAbs Raised by Immunization with Engineered Marburg Virus GPs. 
PLoS Pathog 2015;11:e1005016.

46) Heymann DL, Chen L, Takemi K, Fidler DP, Tappero JW, Thomas MJ, et al. Global health security: the wider lessons from the west African Ebola virus disease epidemic. Lancet
2015;385:1884-901.

47) Centers for Disease Control and Prevention. National Notifiable Diseases Surveillance System (NNDSS). July 2015; http:// wwwn.cdc.gov/nndss/nedss.html (Accessed 1 Oct, 2015). 